\title{
Rimpu Culture In Mbojo Tribe Consumer Behavior In The West Nusa Tenggara Province
}

\author{
Sri Ernawati and Mulyadin \\ Sekolah Tinggi ilmu Ekonomi Bima \\ Email: sriernawati.stiebima@gmail.com
}

\begin{abstract}
Culture is a complex symbol and fact created by humans passed down from generation to generation as a determinant and regulator of human behavior in existing societies. Researcher was interested in researching the Rimpu Cultural Phenomenon influencing Consumer Behavior in the Mbojo tribe community in West Nusa Tenggara. The study was conducted in Mbojo Tribe which included three regional governments, namely Bima City, Bima and Dompu Districts, with the object of research being the Mbojo tribe who bought Bima's unique sarong to be used as Rimpu. Data collection techniques used in this study, namely (a) Qutionary, (b) Observation, (c) Literature study. Research Variable Measurements using likes scale by spreading questionnaire to 100 people, Analysis of data using multiple linear. The results show that Cultural variable, Sub Culture variable and Social Class Variables has an influence on consumer behavior of the Mbojo Tribe in West Nusa Tenggara Province.
\end{abstract}

Keywords: Rimpu, Culture, Sub-Culture, Social Class and Consumer Behavior.

\section{INTRODUCTION}

Humans behave and behave inseparably from the values they profess, both spiritual (religious) values and social and cultural values. These social and cultural values are the result of interactions between individuals and other members of society, which then manifest in various forms of culture such as artifacts, art, ceremonies, language, or values. Values that are believed will determine what is considered good and bad by someone, and the surrounding community, so that it becomes a reference in behaving, and behaving. (Kussudyarsana, 2008)

All company activities are ultimately directed towards thinking about how a product can be felt like a necessity by consumers. If the product produced by the company can provide satisfaction to consumers, the motivation or motivation of consumers to buy the product will arise, so that consumer behavior will arise to meet their needs. (Sulistyowati, 2013). Culture is a complex symbol and fact created by humans "passed down from generation to generation as a determinant and regulator of human behavior in existing societies. Cultural factors have the most extensive in-depth influence on one's behavior. Culture concerns all aspects of human life. At cultural factors, marketers must be able to see the role played by culture, sub-culture, and social classes. (Fathawati, 2017). Consumers consider beforehand about the product they want to buy, whether the product already exists or not, consumer habits in buying are usually based on beliefs about what is 
purchased and what advantages contained in the product. One of the patterns of public consumption of a product is formed due to cultural influences. After they know the product needed, consumers will decide whether to buy or not buy the product. (Suprayitno et al., 2015)

Rimpu is a culture of dressing in the Mbojo (Bima-Dompu) tribal community which contains unique values that are in line with the conditions of an Islamic atmosphere. Today's community culture is now a little forgotten about the culture of the Rimpu, they are more likely to use the veil for more reasons practical, besides that there are still many girls who still do not know how to wear real Rimpu clothes, there are still those who cannot wear Rimpu for reasons that are difficult and take a long time, therefore, they are better off using the hijab as an alternative to closing genitals. This results in reduced demand for typical Bima sarong so that the survival of the weaver decreases and the typical Bima sarong will become more extinct. (Syolihan, 2015)

The culture of Rimpu has begun to be introduced at events or large events such as at events commemorating the Bima sultanate, Bima City birthdays, Bima Regency Anniversary, Dompu Regency Anniversary, Uma Lengge Festival, Tambora charm festival, and many more events held to introduce the culture of Rimpu both locally and nationally even the most recent Rimpu festival in Monas Jakarta. The use of Bima's special sarong for the culture of Rimpu is very beneficial for the weavers of Bima's special sarong because of the need of the mbojo tribe community to use the sarong when the Rimpu is large, so that the demand for the sarong is very high especially when organizing cultural events such as parades, art performances, festivals and others that have already become an annual agenda. This proves that the culture of Rimpu is local wisdom that continues to be preserved because it has a multiplayer effect, where the mbojo tribe community, especially the younger generation knows, then preserves to the international level and the determination of the typical Bima sarong continues to grow along with many consumer demands. (Kataknew, 2018)

Figure 1. Festival Rimpu

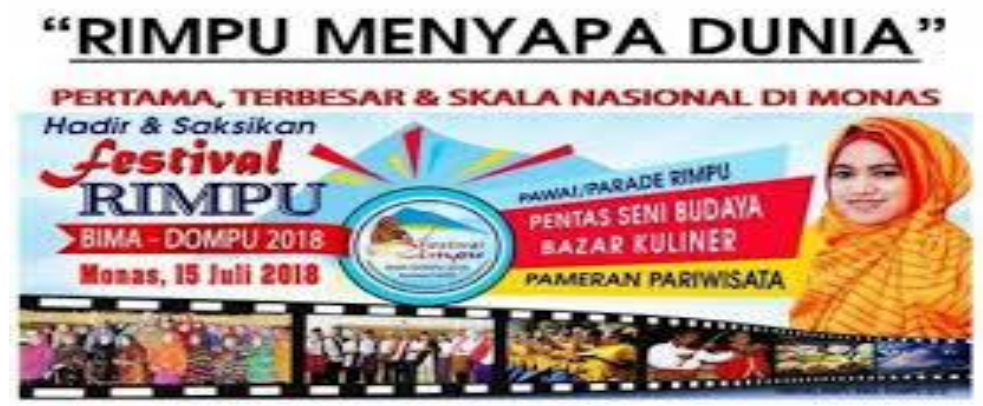

Source: (Kahabanet.com, 2018)

But back to the culture of society today which has now forgotten the culture of the rimpu, they are more likely to wear headscarves for more practical reasons, besides that there are still many girls who still don't know how to wear real rimpu clothes, there are still more can not use rimpu with reason because it is difficult and takes a long time, 
therefore they are better to use the veil as an alternative to cover genitalia. This can result in reduced demand for typical Bima sarong, so that the survival of the weaver decreases and the typical Bima sarong will become more extinct.

Researcher was interested in researching about the phenomenon of Rimpu Culture influencing the emergence of Consumer Behavior in the Mbojo tribal community in West Nusa Tenggara, so that it can be seen how the phenomenon of Rimpu Culture has a positive and significant impact on the emergence of Consumer Behavior in the Mbojo tribe community in West Nusa Tenggara and can provide thought input to The City Government of Bima, Bima Regency, Dompu Regency and the Mbojo tribe community (Bima-Dompu) to continue to preserve the Rimpu culture so that the sustainability of Bima's typical woven sarong products continues to grow because of the high demand for purchases of typical Bima woven sarong.

While the urgency of this research is that culture strongly influences consumer behavior, culture reflects behavior. Consumers will evaluate the product based on the level at which the product helps in achieving cultural value. Consumers will evaluate the consequences they expect and will buy products that they value are able to meet the desired results, besides that the Rimpu Culture has never been studied before at the Bima School of Economics (STIE) and the target of this research is expected to increase the demand for typical Bima gloves so Weaving MSMEs in the Mbojo (Bima-Dompu) tribe continue to develop with varied motifs and patterns in accordance with the desires and needs of consumers which in turn can lead to consumer buying behavior.

\section{THEORETICAL REVIEW}

Culture is the overall beliefs, values, and learning habits that help direct the consumer behavior of certain members of the community (Schiffman and Kanuk, 2013). Culture is a way of life that develops and is shared by a group of people and is passed down from generation to generation. Culture is formed from many complicated elements, including religious and political systems, customs, language, tools, clothing, buildings, and works of art. Besides culture, is an inseparable part of human beings so that many people tend to consider it inherited genetically. When someone tries to communicate with people of different cultures and adjust their differences, proving that culture is learned. (Kussudyarsana, 2008). Cultural factors are the most basic determinants of desire and behavior to get values, perceptions, preferences, and behavior from other important institutions. (Kotler and Keller, 2016).

The indicators used are (Kotler and Keller, 2016):

Culture. Culture is the most basic determining factor in terms of one's desires and behavior because culture involves all aspects of human life. culture is the most fundamental determinant of consumer desires and behavior. Culture / Culture is the beliefs, values, behavior and material objects that are adopted and used by certain communities/societies. Cultural dimensions such as values, artifacts, ideas, and symbols. Sub-culture. Sub-culture consists of nationalities, religions, racial groups, and geographical areas. Many sub-cultures form important market segments, and marketers often design products and marketing programs that are tailored to their needs. Subculture 
is an analysis of units that are important for segmenting a broad market and also analysis units that are important for marketing research. Various sub-cultures, namely national / ethnic sub-culture, religious sub-culture, geographical and regional sub-culture, racial subculture, age sub-culture, gender sub-culture, income sub-culture Social class is a society that is relatively permanent and lasts a long time in a society, arranged in a hierarchical manner and whose membership has similar values, interests and behaviors.

Social class is not determined by one single factor, such as income, but is measured by a combination of income, employment, education, wealth and other variables.

Consumer behavior. Consumer behavior is the study of how individuals, groups, and organizations choose, buy, use, and how goods, services, ideas, or experiences to satisfy their needs and desires (Kotler and Keller, 2016). Consumer behavior is measured based on the following indicators (Kotler and Keller, 2016). (1) Problem Recognition. Usually, consumer purchases based on needs or to solve the needs, problems and interests encountered. If there is no introduction to the problem first, then the consumer will not know which products to buy. (2) Information Search. After knowing the problems experienced, then at that time, a consumer will actively find out about how to solve the problem. In searching for sources or information, a person can do it from oneself (internal) or others (external) such as input, sharing experiences, and so on. (3) Alternative Rating. After consumers get various kinds of information needed in making decisions, then the next thing done by these consumers is to evaluate all alternative decisions and information obtained. That is the basis for overcoming the problems faced. (4) Buying decision. The next process after evaluating the alternative decisions is that the consumer will go through a process called purchasing decisions. The time needed in the decision-making process is not the same, that is, it depends on the things that need to be considered in the buying or decision-making process. (5) Evaluation. The continued process that is usually carried out by a consumer after making the purchase decision and process is to evaluate the purchase. The evaluation includes basic questions such as whether the item is in line with expectations, is appropriate, does not disappoint, and so forth. This will lead to an attitude of satisfaction and dissatisfaction of goods by consumers, disappointing and not disappointing.

Consumer behavior that shows the extent of its commitment to purchase or service use activities, interests related to attitudes and behavior. Interest is considered a "catcher" or intermediary between motivational factors that influence behavior, interest also indicates how hard a person can try (Faisol, 2016). Consumer behavior involves the thoughts and feelings they experience and the actions they take. Consumers need careful thought in making purchasing decisions by comparing products that fit the needs and desires of these consumers. Besides, consumers make purchasing decisions based on the nature that is in themselves, one of which is a sense of wanting to be respected, respected, and to meet their needs and desires. (Saputri, 2016)

Cultural Influences on Consumer Behavior. Basically, the purpose of a business is to create consumer purchase intentions and generate satisfaction for consumers themselves. Companies must understand consumer behavior towards products to be sold to be able to place their products as being able to satisfy the needs and desires of consumers (Sumawar, 2015). Culture as a whole of the beliefs, values, and habits learned that help direct the 
consumer behavior of certain members of the community. Culture is inherent in a consumer, so culture influences consumer behavior because the culture is studied and helps direct consumer behavior (Schiffman and Kanuk, 2013).

Basically, consumers have a fairly complicated buying behavior with differences found in products of the same type but brands and product specifications are generally different (Pratiwi and Mandala, 2015). Culture adheres to a consumer, so culture influences consumer behavior because culture is learned and helps direct consumer behavior (Dwicahyo et all., 2016)

Culture is the most basic determining factor of one's desires and behavior. When other creatures act based on instincts, human behavior is generally studied. A growing child gets a set of perceptual values, preferences and behaviors through a process of socialization that involves the family and other important social institutions (Kotler and Keller, 2016).

With culture, consumer behavior changes. Companies must understand several cultural forms of society, so that it can help marketers predict consumer acceptance of a product. Cultural influences can influence society unconsciously. Cultural influences are so natural and automatic that their effects on behavior are often taken for granted from generations of generation.

Figure 2. State of the Art

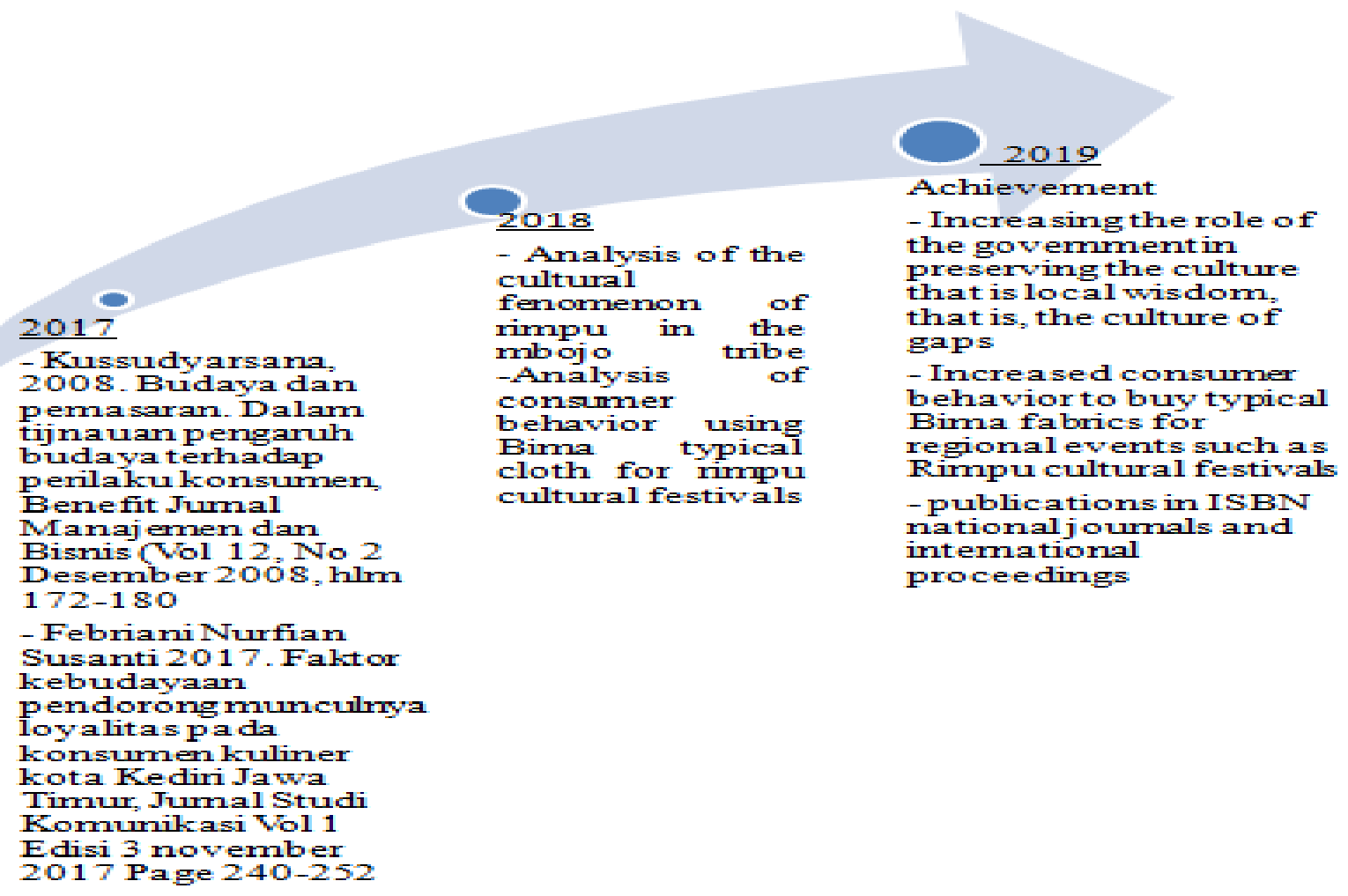

Basically, there is a lot of research on the culture that researches but more specifically examines the culture of new groups in the research that I do. Culture is a way 
of life that is passed down from generation to generation. The elements formed in culture can be said to be very complicated because they are formed in the religious and political system, customs, clothing, language, buildings, works of art to food. So culture is complex, abstract and broad which results in learning by many people (Kussudyarsana, 2008 and Suharto, 2016)

Figure 3. Framework of Tinking Research

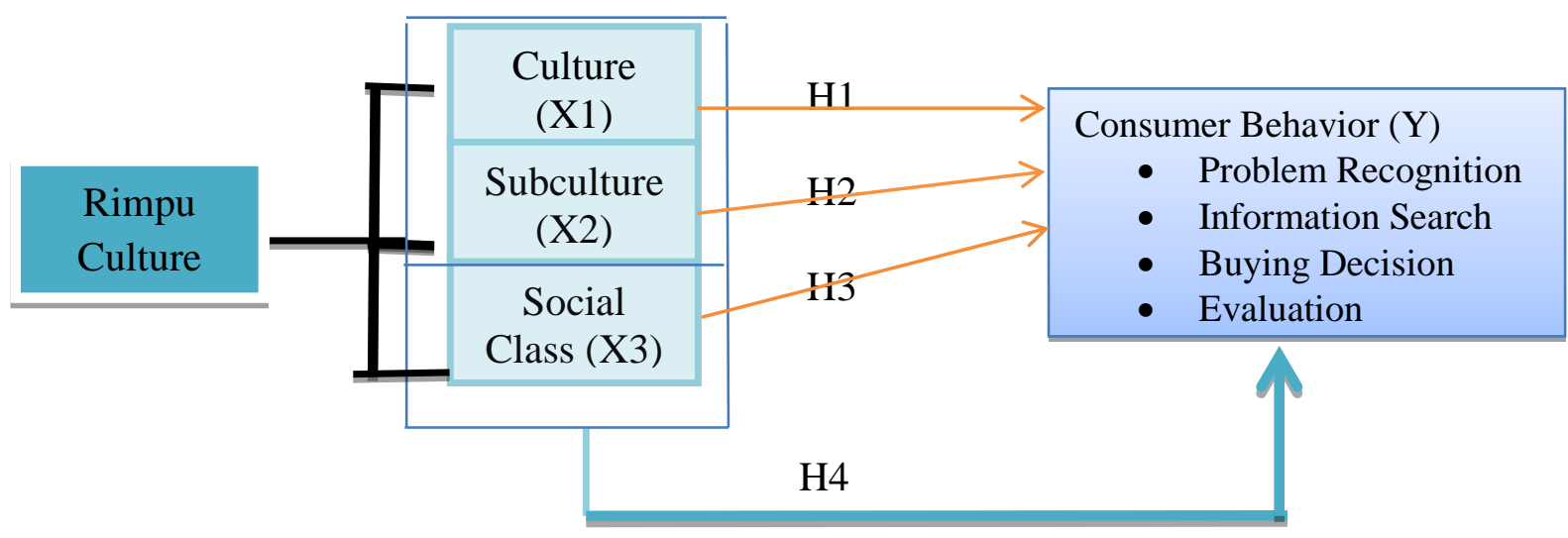

Hypothesis. The scope of this research is about the culture of gaps in consumer behavior, by developing several cultural variables such as Culture, SubCulture and Social Class which are described as follows:

Culture in Mbojo Tribal Consumer Behavior in West Nusa Tenggara Province. According to Consumer culture is the consumer behavior of activities or actions taken by consumers, individuals, groups and organizations in their efforts to assess, obtain and obtain and use goods or services through an exchange process that begins with the decision making process, so as to determine and take actions that can influenced by the environment, so that sometimes two important elements namely the decision making process and physical activity in an effort to meet their wants and needs. (Sunarto, 2018) This factor can be started from them receiving information, their social position in the community, and their knowledge of how they feel. Culture is a fundamental determinant of one's desires and behavior. Then part of the overall iteration of human actions or activities and products produced by humans that have been socially popular and not merely genetically transferred.

H1: Culture influences consumer behavior in the Mbojo tribe in West Nusa Tenggara Province

Sub Culture in Consumption Behavior of the Mbojo Tribe in West Nusa Tenggara Province. The same thing is expressed from the theory (Sumarwan, 2015) states that consumer culture has a different lifestyle, this is evidenced by the existence of consumer objectives where most consumers express the values they hold to satisfy their needs. Marketers must pay attention to the cultural values in each country to understand how to best market their old products and look for opportunities for new products. Each culture consists of several smaller sub-cultures that provide more specific identification and 
socialization for their members. Sub-cultures include nationalities, religions, racial groups, and geographical areas. When sub-cultures grow big and rich enough, companies often design marketing programs specifically to serve them. Not only about culture and subculture.

H2: SubCulture influences consumer behavior in the Mbojo tribe in West Nusa Tenggara Province

Social Class in Mbojo Tribal Consumer Behavior in West Nusa Tenggara Province. Social class is an important variable in determining where consumer shopping. Different social classes have different perspectives on what consumers think is appropriate to their fashion or good taste, (Schiffman and Kanuk, 2013)

H3: Social class influences Consumer Behavior in the Mbojo tribe in West Nusa Tenggara Province.

Culture, SubCulture, and Social Class together influence jointly on Mbojo Tribe Consumer Behavior in West Nusa Tenggara Province. Society is the most dynamic thing. Why is that? Due to changes in society that can not be dammed. This change occurs in every aspect of society, (Kotler and Keller, 2016) argues that culture is a determinant of desire and reference behavior, and human behavior is determined at its most basic. Each culture consists of smaller sub-cultures which give more characteristics and special socialization to their members. Subculture consists of nation, religion, racial group, and geographical area. Many sub-cultures form important market segments by designing products and marketing programs that are tailored to the needs of consumers. A company makes products according to the area where the product is marketed (Kotler and Keller, 2016). Social class refers to income or purchasing power. social class also influences consumer buying behavior. (Kotler and Keller, 2016) continued, almost all groups of people experience social stratification, often in the form of social class, relatively homogeneous and enduring divisions in society arranged hierarchically and have members who share values, interests, and the same behavior.Culture is a complex symbol and fact created by humans "passed down from generation to generation as a determinant and regulator of human behavior in existing societies. Cultural factors have the most extensive in-depth influence on one's behavior. Culture concerns all aspects of human life. At cultural factors, marketers must be able to see the role played by culture, sub-culture, and social classes. (Fathawati, 2017)

H4: Culture, SubCulture and Social Class together influence jointly on Mbojo Tribe Consumer Behavior in West Nusa Tenggara Province.

\section{METHODOLOGY}

This research uses research in quantitative research with a survey approach. The population in this research was conducted in the Mbojo Tribe in three regional government areas, namely the City of Bima, Bima Regency and Dompu Regency, with the population being the entire Mbojo tribe community who had bought a typical Bima cloth to be used as Rimpu. (Riduwan, 2015), because the number of buyers and users using 
Rimpu and buying typical Bima fabrics is very large, and it is impossible to examine all due to many limitations, the number of samples used is as much as 96.4 respondents, can be rounded up to 100 respondents so Respondent data is more representative of the population. The sampling technique with purposive sampling is by determining specific characteristics that are following the objectives of the study so that it is expected to answer the research problem.

Data collection is done by taking data surveyed by distributing a list of statements in the form of questionnaires, observations that aim to get in-depth information about the culture of rhizomes in Mbojo Tribal consumer behavior and literature study to take quotes from various sources of literature.

The measurement of variables in this study is the culture of the group with culture (X1), subculture (X2) and social class (X3) and Consumer Behavior as the dependent variable (Y) with several indicators as benchmarks to see the effect between variables $\mathrm{X} 1$, $\mathrm{X} 2$, and $\mathrm{X} 3$ and $\mathrm{Y}$ variables. Measurement using variable Likers scale. Likert scale is used to measure the attitudes, opinions, and perceptions of a person or group of people about social phenomena (Sugiyono, 2016).

Data analysis uses multiple linear regression, which is where the writer wants to know and analyze the culture of Rimpu in the consumer behavior of the Mbojo tribe in West Nusa Tenggara Province. The regression equation model is as follows: $Y=a+b_{1} x_{1}$ $+b_{2} x_{2}+b 3 x 3$. Analyzes were performed using SmartPLS

\section{THE RESULTS OF STATISTICAL TESTS}

Characteristics of Respondents where the number of questionnaires distributed in the three research areas, namely Bima City, Bima Regency, and Dompu Regency. Classification of respondents based on education level, namely Senior High School (SMA) 9 people with a percentage of 9\%, Associate Expert (D3) 15 people with a percentage of $15 \%$, Bachelor degree (S1) 72 people with a percentage of $72 \%$ and Bachelor Degree 4 people with $4 \%$ percentage. Classification of respondents based on the type of work, namely Civil Servants (PNS) 82 people with a percentage of $82 \%$, Honorary 9 people with a percentage of $9 \%$, Private employees 4 people with a percentage of $4 \%$ and Housewives 5 people with a percentage of $5 \%$.

Model Prerequisite Test 1. Prerequisite tests used are reliability and ave. The following are the prerequisite test results 
Table 1. Model 1 Prerequisite Test

\section{Construct Reliability and Validity}

\begin{tabular}{|c|c|c|c|c|c|c|c|c|c|}
\hline \multirow[t]{2}{*}{ 婳 } & \multirow[t]{2}{*}{ Matrix } & \multirow[t]{2}{*}{ 㩲莘 } & Cronbach's Alpha & 掉昔 rho_A & 掉草 & Composite Reliability & \multicolumn{2}{|c|}{ 掉等 Average Variance Extracted (AVE) } & \multirow[b]{2}{*}{ Extracte... } \\
\hline & & & \multicolumn{3}{|c|}{ Cronbach's Alpha } & rho_A & Composite Reliability & Average Variance Extracte... & \\
\hline $\mathrm{X} 1$ & & & & 0.819 & & 0.836 & 0.868 & & 0.526 \\
\hline$X_{2}$ & & & & 0.729 & & 0.786 & 0.806 & & 0.425 \\
\hline X3 & & & & 0.857 & & 0.897 & 0.897 & & 0.603 \\
\hline$Y$ & & & & 0.810 & & 0.815 & 0.868 & & 0.530 \\
\hline
\end{tabular}

Source : (primary data processed SmartPLS, 2019)

Based on the table above shows the AVE value on the variable X2 returned from 0.5 so it is necessary to improve the model by eliminating the indicator on X2 which has the lowest outer loading value. Outer Loding results can be seen in the table below.

Figure 4. Result Outer Loding model 1

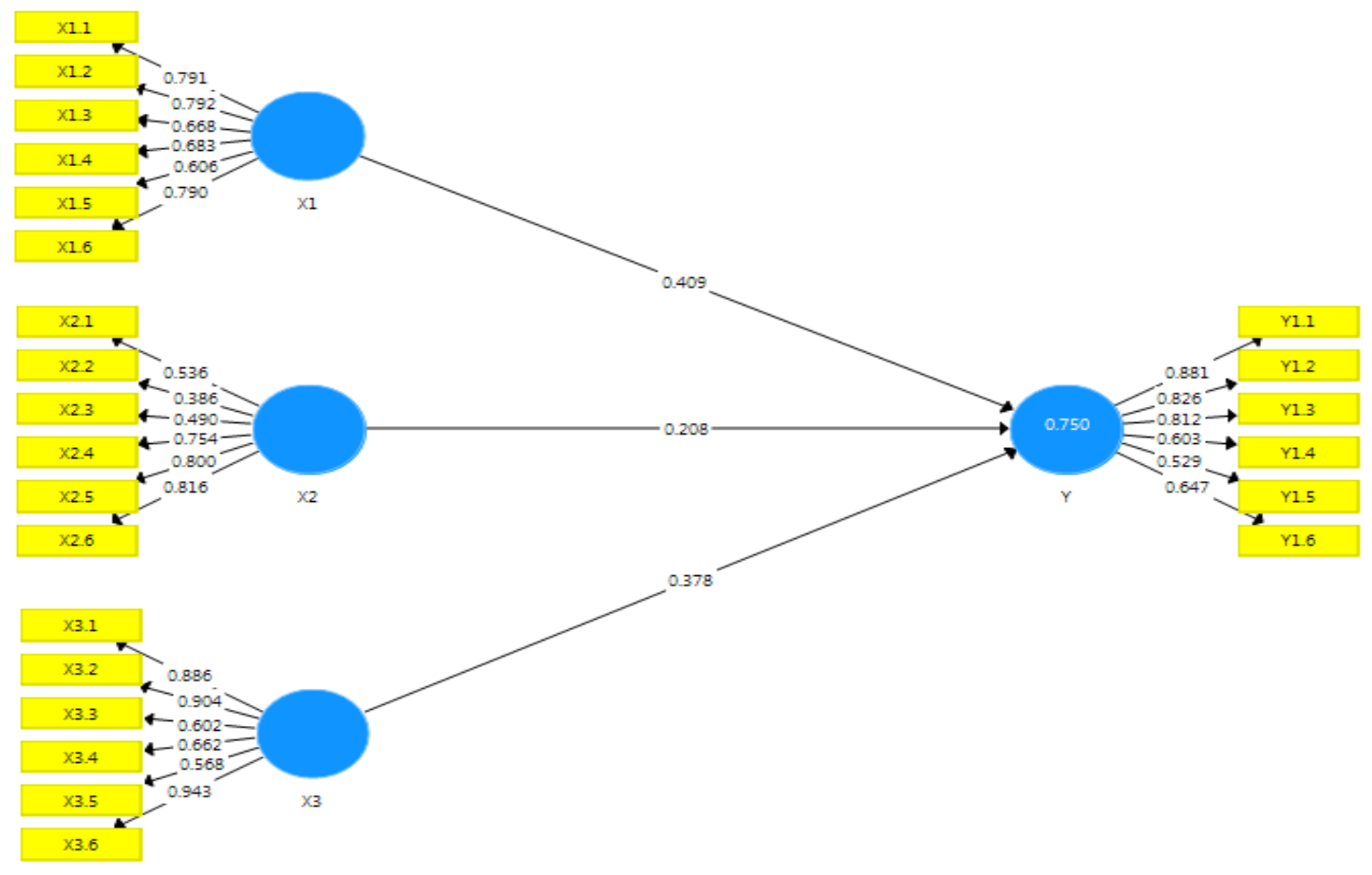

Based on the table above, it is obtained that indicator X2.3 has the lowest outer loading value, so both indicators can be excluded from the model.

\section{Model 2 Prerequisite Tests}

Model 2 prerequisite tests used as used in model 1. The following are the results of the model 2 prerequisite tests 
Table 2. Prerequisite Test Model 2

\section{Construct Reliability and Validity}

\begin{tabular}{|c|c|c|c|c|c|c|c|c|}
\hline \multirow[t]{2}{*}{ 囯 } & \multirow[t]{2}{*}{ Matrix } & \multirow[t]{2}{*}{ 掉萃 } & \multirow{2}{*}{$\begin{array}{c}\text { Cronbach's Alpha } \\
\text { Cronbach's Al... }\end{array}$} & \multirow[t]{2}{*}{ 拱萃 rho_A } & \multirow{2}{*}{ O_A } & Composite Reliability & \multicolumn{2}{|c|}{ 㩰亲 Average Variance Extracted (AVE) } \\
\hline & & & & & & Compo & site Reliability & Average Variance Extract... \\
\hline $\mathrm{X} 1$ & & & 0.819 & & B36 & & 0.868 & 0.526 \\
\hline$x_{2}$ & & & 0.720 & & 770 & & 0.816 & 0.483 \\
\hline$x_{3}$ & & & 0.857 & & 897 & & 0.897 & 0.603 \\
\hline $\mathrm{Y}$ & & & 0.810 & & $\mathbf{B 1 5}$ & & 0.868 & 0.530 \\
\hline
\end{tabular}

Source: (primary data processed SmartPLS, 2019)

Based on the table above shows the value of AVE on the variable X2 is less than 0.5 , so we need to improve the model by eliminating the indicator on X2 which has the lowest outer loading value. Outer Loding results can be seen in the table below.

Figure 5. Result outer loding model 2

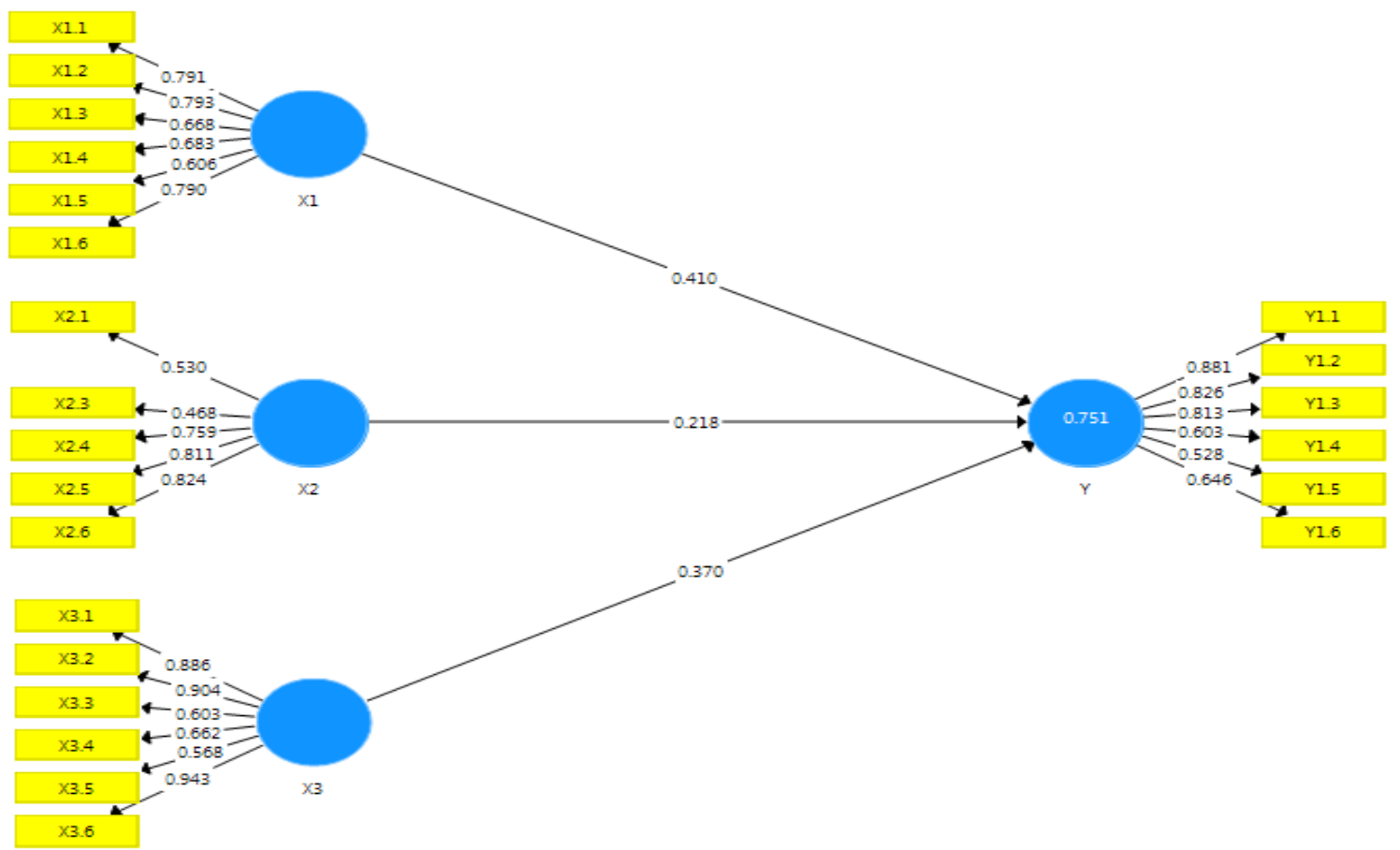

Based on the path above obtained information X2.3 indicator has the lowest outer loading value, so both indicators can be excluded from the model.

Model 3 Prerequisite Tests. Model 2 prerequisite tests are used as used in model 1 and model 2. The following are the results of the model 3 prerequisites 
Table 3. Model 3 Prompt Test

Construct Reliability and Validity

\begin{tabular}{|c|c|c|c|c|c|c|c|c|}
\hline \multirow[t]{2}{*}{ Matrix } & 楛竞 & Cronbach's Alpha & 掉算 rho_A & 㩲萃 & Composite Reliability & 掉竞 Aver & Extracted (AVE) & Copy to C \\
\hline & & Cronbach's Al... & \multicolumn{2}{|c|}{ rho_A } & \multicolumn{2}{|c|}{ Composite Reliability } & \multicolumn{2}{|c|}{ Average Variance Extracted (AVE) } \\
\hline $\mathrm{X} 1$ & & 0.819 & & 836 & & 0.868 & & 0.526 \\
\hline$X 2$ & & 0.726 & & 760 & & 0.833 & & 0.563 \\
\hline Y & & 0.810 & & 816 & & 0.868 & & 0.530 \\
\hline
\end{tabular}

Source: (primary data processed SmartPLS, 2019)

Based on the table above shows the value of AVE on the variables X1, X2 and X3 nothing less than 0.5 , so no improvement is needed because the model does not have the lowest outer loading value. Outer Loding results can be seen in the table below.

Figure 6. Result outer loding model 3

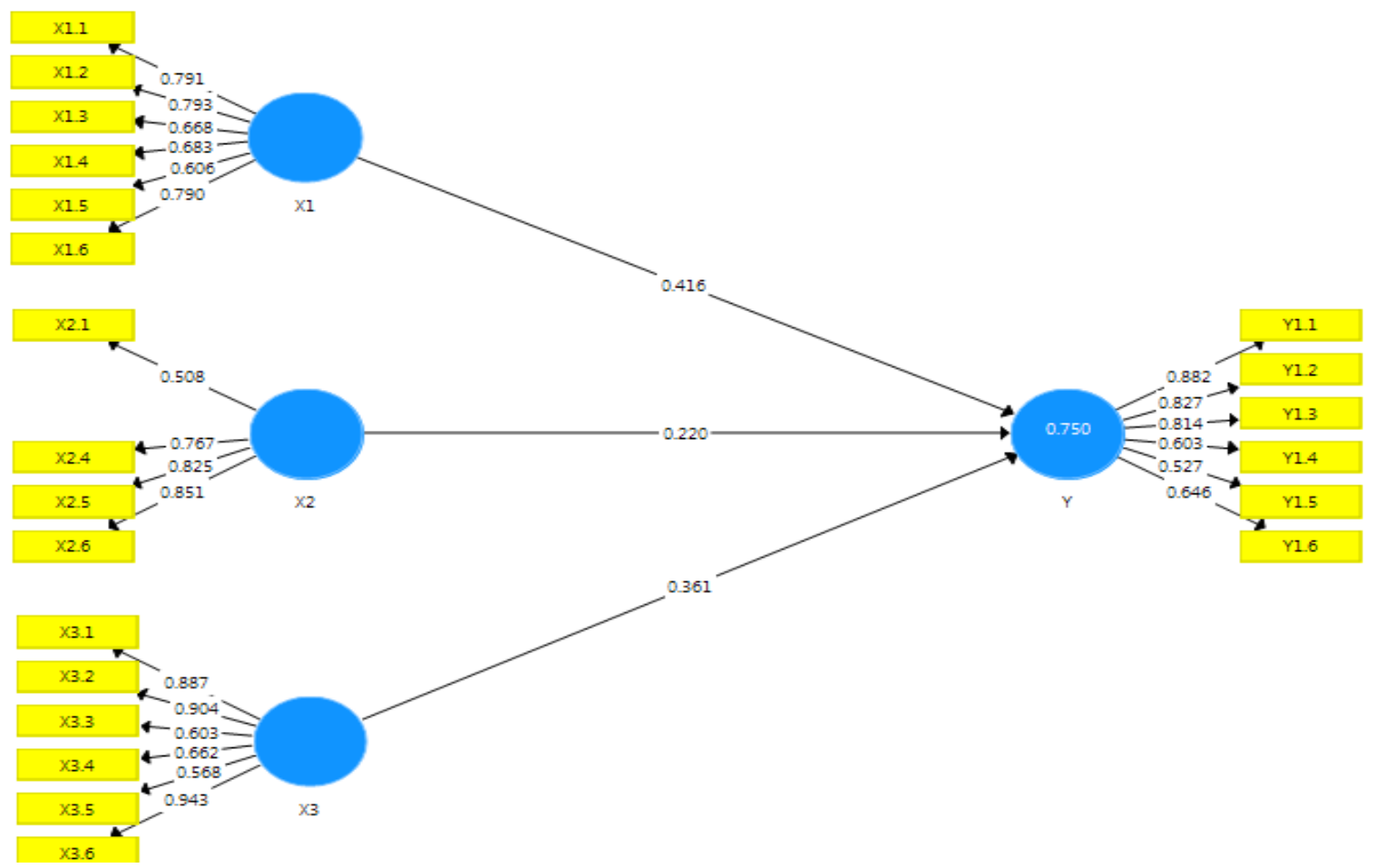

Based on the path above obtained information X2.3 indicator has the lowest outer loading value, so both indicators can be excluded from the model. 


\section{Multicollinearity test}

Table 4. Result Multicollinearity test

\section{Collinearity Statistics (VIF)}

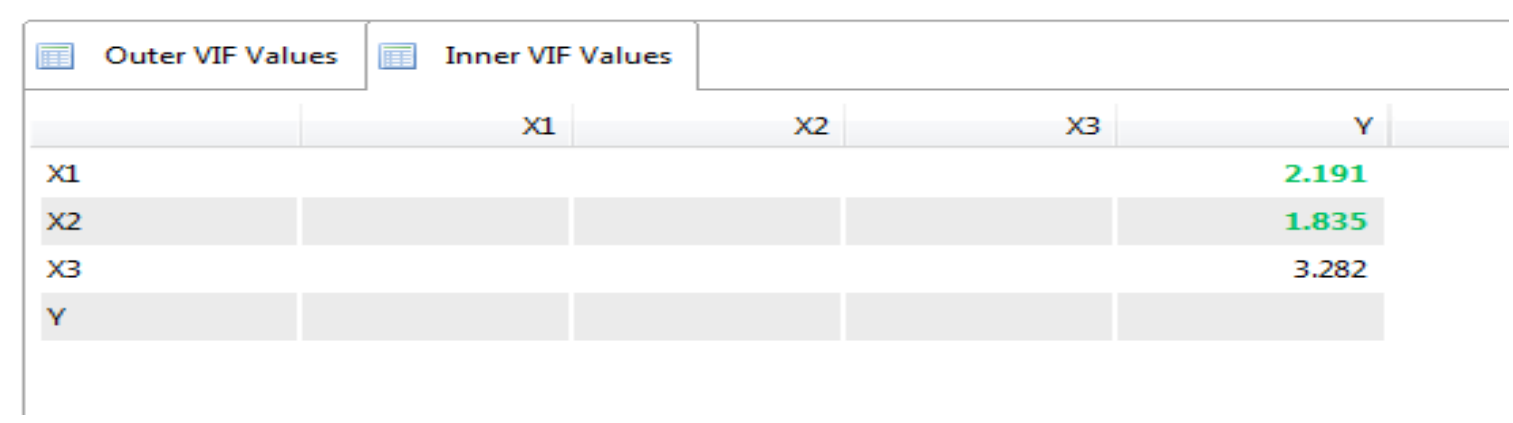

Source : (primary data processed SmartPLS, 2019)

From the table above it can be seen that the VIF value is below 10, so it can be said that Multicolliniearity does not occur.

Multiple Regression Test. T-test was conducted to determine the effect of the independent variables on the dependent variable both together and partially. The results of the hypothesis testing with smart PLS both the joint and partial hypotheses of influence can be seen in the table below.

Table 5. Result Analysis Multiple Regression Test

Path Coefficients

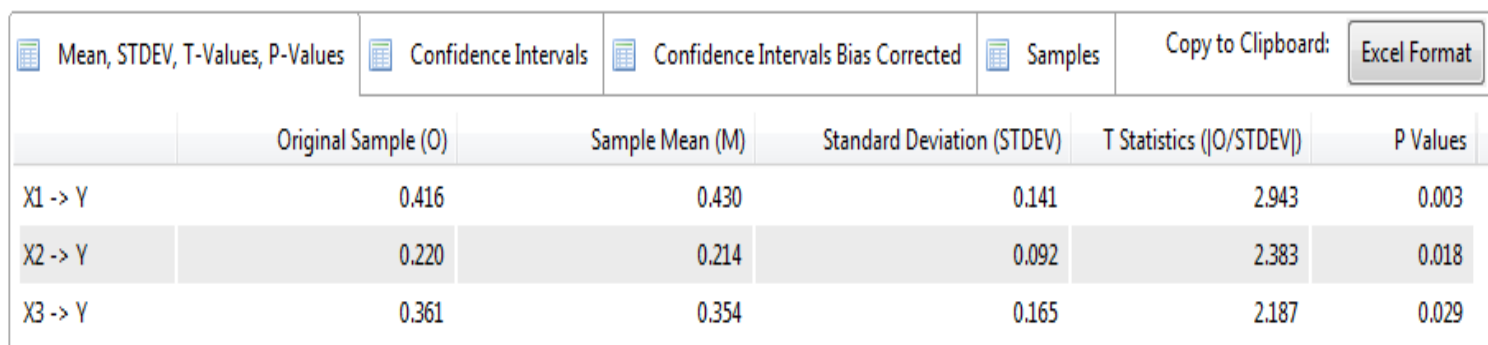

Source: (primary data processed SmartPLS, 2019)

Table 6. From the results of the regression analysis we can find the multiple regression equation as follows:

$$
Y=0,416 X_{1}+0,220 X_{2}+0,361 X_{3}
$$

Based on these equations, it can be explained as follows:(1) The beta coefficient value on the Culture variable is 0,416 meaning that every change in the Culture variable (X1) is one unit, it will cause a change in Consumer Behavior of 0,416 units, with other assumptions that are fixed. One unit increase in Culture variable will increase Consumer Behavior by 0,416 units. (2) The beta coefficient value on Bub Culture variable is 0,220 meaning that every change of Bub Culture (X2) variable is one unit, it will cause a change 
in Consumer Behavior of 0,220 units, with other assumptions that are fixed. One unit increase in Bub Culture variable will increase Consumer Behavior by 0,220 units. (3) The beta coefficient value on the Social Class variable is 0,361 meaning that every change in the Social Class variable (X2) is one unit, it will cause a change in Consumer Behavior of 0,361 units, with other assumptions that are fixed. One unit increase in the Social Class variable will increase Consumer Behavior by 0,361 units.

Hypothesis testing. Furthermore, to find out whether the hypothesis proposed in this study was accepted or rejected, the hypothesis test will be carried out using the t-test. The results of testing the hypothesis are explained as follows:

Table 6. Result Analysis Multiple Regression Test Coefficients ${ }^{\mathrm{a}}$

\section{Path Coefficients}

\begin{tabular}{|c|c|c|c|c|c|c|c|}
\hline \multirow[t]{2}{*}{ Mean, STDEV, } & , T-Values, P-Values & Confidence Intervals & 圆 Confidence Int & Vals Bias Corrected & 固 Samples & Copy to Clipboard: & Excel Format \\
\hline & \multicolumn{2}{|c|}{ Original Sample (0) } & Sample Mean (M) & Standard Deviatio & on (STDEV) T & TStatistics (I/STDEV) & PValues \\
\hline$X 1 \rightarrow Y$ & & 0.416 & 0.430 & & 0.141 & 2.943 & 0.003 \\
\hline$X 2 \rightarrow Y$ & & 0.220 & 0.214 & & 0.092 & 2.383 & 0.018 \\
\hline$X 3 \rightarrow Y$ & & 0.361 & 0.354 & & 0.165 & 2.187 & 0.029 \\
\hline
\end{tabular}

Source: (primary data processed SmartPLS, 2019)

Culture in Mbojo Tribal Consumer Behavior in West Nusa Tenggara Province.

H1 = Culture influences Consumer Behavior of the Mbojo Tribe in West Nusa Tenggara Province

The results of the t-test statistics for the Culture variable obtained the t-count value of 2.943 with a significance value of 0,003 less than $0.05(0,03 \%<5 \%)$, then the hypothesis stating that "Culture influences Consumer Behavior of the Mbojo Tribe in West Nusa Tenggara Province" Accepted ". This research is the same as research conducted by (RahadinidanWibowo, 2018) which states that Culture influences Buying Decision this can be seen from the $\mathrm{t}$ value of 3,985 with a significant value of $0.000<0.005$, (Bahari, Faisal and Ashoer Muhammad, 2018) which state that Culture have a significant influences on partial buying decision, where t count 2,595 and significant $0,010<0,05$ and Nayeem (2012) which state that culture influences car purchases in Australia, where companies know their marketing strategy by first knowing the culture of their people.

\section{Sub Culture in Consumer Behavior of the Mbojo Tribe in West Nusa Tenggara Province. \\ $\mathbf{H 2}=$ Sub-Culture influences Consumer Behavior of the Mbojo Tribe in West Nusa Tenggara Province.}


The results of the t-test statistic for the Sub Culture variable obtained the t-count of 2,383 with a significance value of $0,018(1,8 \%<5 \%)$, then the hypothesis stating that "SubCulture influences Consumer Behavior of the Mbojo Tribe in West Nusa Tenggara Province "Accepted. This research differs from research conducted by (Giantara and Santoso J, 2014) which states that SubCulture does not influence the buying behavior of traditional cakes by students in Surabaya named $t$ count $<t$ table $(0.0698<1.97490)$

\section{Social Class in Consumer Behavior of the Mbojo Tribe in West Nusa Tenggara Province. \\ H3 = Social Class influences Consumer Behavior of the Mbojo Tribe in West Nusa Tenggara Province.}

The results of the t-test statistics for the Social Class variable obtained t-count value of 2.187 with a significance value of $0,029(2,9 \%<5 \%)$, then the hypothesis stating that "Social Class has an effect on consumer behavior of the Mbojo Tribe in West Nusa Tenggara Province "Accepted. This research is the same as research conducted by (Nugraheni, 2018) which states that Social Classes influence Consumer Behavior (Study on home purchases in PERUM PERUMNAS Mojokerto branch location in Madiun), where this can be seen from $t$ Count $>t$ table $(15,163>1.67252)$.

\section{Culture, SubCulture, and Social Class together influence jointly on Consumer Behavior in the Mbojo tribe in West Nusa Tenggara Province.}

H4 = Culture, Sub-Culture and Social Classes influence the Consumer Behavior of the Mbojo Tribe in West Nusa Tenggara Province.

The results of the t-test statistics for the Culture, Sub-Culture and Social Class variables obtained a t-count of 99,513 with a t-table of $1,37(99,513>1,37)$ with a significance value of $0,000(0,000<0,05)$, then the hypothesis stating that "Culture, SubCulture, and Social Class together influence jointly on Consumer Behavior in the Mbojo tribe" Accepted. This study is the same as research conducted by (Giantara and Santoso , 2014) which states that the coefficient shows a positive number on the four variables, namely culture, sub-culture, social class, and perceived quality that influence the behavior of traditional cake purchasing decisions by students in Surabaya and research by (Paramitha, 2015) Found that the most dominant cultural factor influenced the selection of bridal make up, culture, Sub-Culture and social class result ini identification of specific cultural segments in using body care services 


\section{f Square Test}

Table 7. Result f Square test

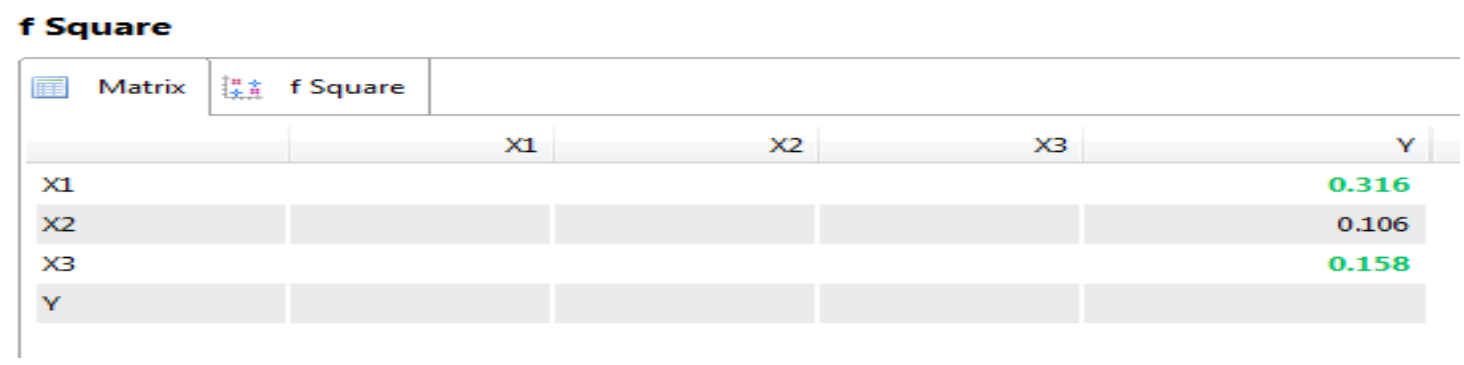

Source: (primary data processed SmartPLS, 2019)

The results of the f Square test statistics for the Culture, Sub-Culture and Social Class variables obtained effect size: (1) The value of $\mathrm{f}^{2} \mathrm{X} 1$ (Culture) of 0,316 is categorized as the influence of the strong predictor latent variable (exogenous latent variable) at the structural level. (2) The value of $\mathrm{f}^{2} \mathrm{X} 2$ (Sub-Culture) as big as 0.106 is categorized as sufficient influence of the predictor latent variable (exogenous latent variable) at the structural level. (3) The $\mathrm{f}^{2} \mathrm{X} 3$ (Social Class) value of 0.158 is categorized as the effect of a sufficient latent predictor variable (exogenous latent variable) at the structural level.

\section{Determination Test}

Table 8. Result Determination Test

R Square

\begin{tabular}{|c|c|c|c|c|c|}
\hline \multirow[t]{2}{*}{ 圂围 } & Matrix & 彗草 & R Square & 接育 R Square Adjusted & \\
\hline & & & \multicolumn{2}{|c|}{ R Square } & Square Adjusted \\
\hline$Y$ & \multicolumn{4}{|r|}{0.750} & 0.742 \\
\hline
\end{tabular}

Source: (primary data processed, Smart PLS2019)

Determination Test Results, Adjusted R2 in this study obtained a value of 0.757 . This shows that Consumer Behavior (Y) is influenced by Culture (X1), SubCulture (X2) and Social Class (X3) by $0,742=74,2 \%$, while the remaining $25.8 \%$ is influenced by other factors not included in this study.

\section{CONCLUSION}

The conclusion that can be drawn from this study is that the Cultural Variable (X1) has an influence on consumer behavior of the Mbojo Tribe in West Nusa Tenggara Province, Sub Culture variable (X2) has an influence on the Consumer Behavior of the Mbojo Tribe in West Nusa Tenggara Province, Social Class Variables (X3) have an influence on the Consumer Behavior of the Mbojo Tribe in West Nusa Tenggara Province 
and simultaneously the variable Culture (X1), Sub Culture (X2) and Social Class (X3) influences the Consumer Behavior of the Mbojo Tribe in West Nusa Tenggara Province. In this study, researchers did not describe clearly how the state of the mbojo tribe in terms of aspects of daily life, activities that are usually carried out and the use of typical Bima cloth for activities other than Rimpu. In future research, researchers must add other variables that influence consumer behavior such as social, personal, psychological and other variables that affect consumer behavior

Overall Recommendations. Local governments within the Mbojo Tribe area, namely Bima City, Bima Regency and Dompu Regency must synergize with one another by continuing to preserve the culture of Rimpu through regional, national and international events so that the cultural heritage of ancestral heritage can continue to be preserved at any time and the culture of this Rimpu must be legitimized through patents so that it is not claimed by other regions or even other countries.

\section{REFERENCES}

Bahari, Faisal dan Ashoer Muhammad, (2018). Pengaruh Budaya, Sosial, Pribadi Dan Psikologis Terhadap Keputusan Pembelian Konsumen Ekowisata. Jurnal Manajemen, Ide, Inspirasi (MINDS) Vol.5, No. 1, (Januari-Juni): 69-78.

Dwicahyo, Adiarni dan Najamuddin. (2016), Pengaruh Konsep Produk, Budaya Konsumsi, dan Keluarga Terhadap Perilaku Konsumen Mengkonsumsi Produk Kebab (Studi Kasus: Kebab Turki XXX). Jurnal Teknologi dan Manajemen Agroindustri Vol 6 No.1 pp. 8-14.

Faisol Akhmad dan Hening Widi Oetomo, (2016).Pengaruh Budaya, Harga dan Lokasi Terhadap Minat Belanja Konsumen Di Pasar Soponyono. Jurnal Ilmu dan Riset Manajemen: Volume 5, Nomor 2.

Fathawati, Moh. Hufron dan Afi Rahmat Slamet, (2017). Pengaruh Budaya, Sosial, Pribadi dan Psikologis Terhadap Keputusan Pembelian Mie Instan Merek "Mie Sedaap. e-Jurnal Riset ManajemenProdi Manajemen Fakultas Ekonomi Unisma website : www.fe.unisma.ac.id (email : e.jrm.feunisma@gmail.com)

Febriani Nufian Susanti. (2017), Faktor Kebudayaan Pendorong Munculnya Loyalitas Pada Konsumen Kuliner Kota Kediri Jawa Timur. Jurnal Studi Komunikasi Vol. 1 No. 3.

Kataknew, (2018), Syantik, Festival Rimpu Bima Dompu memukau warga Jakarta. diakses 25 Mei 2018 dari http://www.kataknews.com/2018/07/festival-rimpu-bimadompu-memukau.html.

Kussudyarsana. (2008), Budaya dan Pemasaran Dalam Tinjauan Pengaruh Budaya Terhadap Perilaku Konsumen. Benefit Jurnal Manajemen dan Bisnis Vol. 12 No.2.

Kotler, Philip dan Keller, Kevin Lane. (2016). Marketing Manajemen, Edisi 15, Penerbit Pearson Education 2016.

Ilham, Hermawati. (2018). Pengaruh Faktor Kelas Sosial Terhadap Perilaku Konsumen Dalam Pemilihan Pakaian Di Desa Lagego Kecamatan Burau Kabupaten Luwu Timur . DINAMIS- Journal of Islamic Management And Bussines Vol. 1 No. 1. 
Nayeem Tahmid, (2012). Cultural influences on customer behavior. Internasional Journal

Of Business And Management And Education, Vol 7, No 21 Online Published: October 18, 2012.

Mariani Shoshana Giantara dan Jesslyn Santoso, (2014). Pengaruh Budaya, Sub Budaya, Kelas Sosial, Dan Persepsi Kualitas Terhadap Perilaku Keputusan Pembelian Kue Tradisional Oleh Mahasiswa Di Surabaya. Jurnal Hospitality dan Manajemen Jasa Vol. 2 No. 1.

Paramitha, Catra Tiara. (2015). Minat Konsumen dalam Pemilihan Tata Rias Pengantin Tradisional dan Modifikasi di Salon Kemuning Purwokerto. e- Journal. Volume 04 Nomer 02, Edisi Yudisium Periode Juni 2015, hal 16-21.

Pratiwi Indah ketut dan Mandala Kastawan. (2015). Pengaruh Faktor Budaya, Sosial, Pribadi, psikologis, dan Bauran Pemasaran Terhadap keputusan Pembelian Kebaya Bordir Pada Jegeg Ayu Boutique Di Kuta. E-Jurnal Manajemen Unud, Vol. 4 No. 11.

Rahadhini, Desman marjam dan Wibowo Edi, (2018). Analisis Pengaruh Faktor Penentu Pengambilan Keputusan Pembelian Konsumen Tengkleng Di Surakarta. Seminar Nasional dan Call for paper Sustainable Competitive advance (SCA) 8.

Ria Dwi Nugraheni, (2018). Pengaruh Kelas Sosial Terhadap Perilaku Konsumen (Studi Pada Pembelian Rumah Di Perum Perumnas Cabang Mojokerto Lokasi Madiun). Jurnal ilmiah ekonomi dan pembelajaran Vol. 6 No. 1.

Riduwan. (2015). Dasar-DasarStatistik, Bandung:Alfabeta.

Saputri, Eka Marheni, (2016). Pengaruh Perilaku Konsumen Terhadap Pembelian Online Produk Fashion Pada Zalora Indonesia . Jurnal Sosioteknologi| Vol. 15, No 2.

Schiffman, Leon and Kanuk, Leslie L. (2013). Consumer Behavior. ${ }^{\text {th }}$ edition.NewJersy:Prentice Hall.

Sugiyono. (2016). Metode Penelitian Pendidikan Pendekatan Kuantitatif, Kualitatif, dan R\&D. Bandung: Alfabeta.

Sulistyowati, Eny, (2013). Motivasi dan Perilaku Konsumen Dalam Keputusan Pembelian Produk Industri Kerajinan Kulit Di Yogyakarta. Jurnal MAKSIPRENEUR, Vol. II, No. 2, Juni 2013, [17 - 26].

Sunarto, (2018). Analisis Perilaku Konsumen Terhadap Keputusan Pembelian Handphone Xiaomi Redmi 3S. Jurnal Moneter Vol. V No. 1.

Suharto. (2016), Pengaruh Budaya Terhadap Keputusan Pembelian Menggunakan Variable Sosial dan Pribadi Sebagai Mediasi Produk Air Minum Kemasan (Studi Empiris Pada PT. Gloz di Lampung Timur). Jurnal Derivatif Vol. 10 No. 1.

Sumarwan, Ujang, (2015) Perilaku Konsumen., Teori dan Penerapannya Dalam Pemasaran. Edisikedua. Cetakanketiga, Bogor: Penerbit Ghalia Indonesia.

Suprayitno, Rochaeni dan Purnomowati, (2015). Pengaruh Faktor Budaya, Sosial, Pribadi, dan Psikologi Konsumen Terhadap Keputusan Pembelian Pada Restoran Gado-Gado Boplo (Studi Kasus: Restoran Gado-Gado Boplo Panglima Polim Jakarta Selatan) Jurnal Agribisnis, Vol. 9, No. 2, Desember 2015, [ 177 - 214 ].

Syolihan Maratun, (2015). Budaya Rimpu Suku Mbojo. NTB, diakses 25 Mei 2019 dari https://www.kompasiana.com/www.kompasiana.commaratunsyolihan/552abd0c6ea $\underline{\text { 834e838552cf6/budaya-rimpu-suku-mbojo-ntb. }}$ 